\title{
Insights on food and nutrition in the Federated States of Micronesia: a review of the literature
}

\author{
Lois Englberger ${ }^{1, *}$, Geoffrey C Marks ${ }^{1}$ and Maureen H Fitzgerald ${ }^{2}$ \\ 'Nutrition Program, Division of International Health, School of Population Health, University of Queensland, \\ Brisbane, Australia: ${ }^{2}$ School of Occupation and Leisure Sciences, University of Sydney, Sydney, Australia
}

Submitted 7 January 2002: Accepted 13 June 2002

\begin{abstract}
Background: Nutrition-related disorders, including vitamin A deficiency (VAD) and chronic diseases, are serious problems in the Federated States of Micronesia (FSM). Many suggest that these disorders are new problems related to dietary and lifestyle changes. In the past four decades, imported foods, such as white rice, flour, sugar, refined foods and fatty meats, have increasingly replaced local foods in the diet. Aim: A literature review was conducted to understand underlying issues related to dietary change and obtain insights for nutrition research and interventions.

Method: Published and unpublished papers from different disciplines were reviewed and collated for information on food and nutrition in FSM. Topics covered were historical background, local foods, infant and child feeding, dietary assessment, and nutritional status. Particular focus was on information and data relating to VAD, the primary topic that led to the review of the literature.

Conclusions: FSM, a tropical country of abundant agricultural resources, has suffered a great loss in production and consumption of local foods. Inconsistent external and internal government policies and food aid programmes have contributed to the problem. Further research on the nutrient content of local foods and factors affecting production, acquisition and consumption is needed, as well as a broad, well-planned, intersectoral intervention aimed at dietary improvement for all age groups in the population.
\end{abstract}

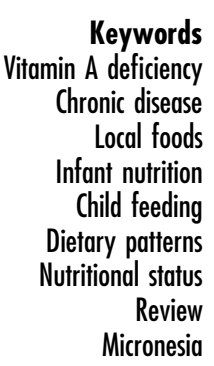

Health and nutrition literature concerning the Federated States of Micronesia (FSM) is limited; however, literature from other disciplines such as anthropology, agriculture, geography, history and environmental science contribute important information for the present situation of food and nutrition. This multidisciplinary review was undertaken to provide background for understanding the food and nutrition situation in FSM, with particular focus on the current status of vitamin A deficiency (VAD) in FSM.

FSM is made up of four states and 607 islands (atoll and volcanic) spread over the western Pacific Ocean ${ }^{1}$. The population is around 107000 (Chuuk, 53600; Pohnpei, 34 500; Yap, 11 200; Kosrae, 7700) ${ }^{2}$, and includes people with many cultural identities. Agricultural resources are adequate in general (atoll islands having poorer soils and less rainfall than volcanic islands). Rainfall $(\sim 250-500 \mathrm{~cm}$ annually) $)^{3}$ and temperatures (annual average $\left.27^{\circ} \mathrm{C}\right)^{1}$ are high. Agriculture, the predominant occupation for most people, is mainly on a subsistence level.

The traditional diet was based on meals of cooked starchy staples, fish and seafood ${ }^{4-14}$, with fruits and sugar cane eaten as snacks ${ }^{6,10}$, and vegetables (other than starchy staples) not commonly eaten. This diet has been considered by commentators to be very healthy ${ }^{15-21}$. In the past there were problems with infectious diseases ${ }^{22,23}$ and intestinal parasites ${ }^{20,24}$, but diabetes and hypertension were unusual ${ }^{25,26}$, and there was little evidence of malnutrition $^{22,23}$.

The diet has changed significantly since World War II. Imported white rice, flour, sweet and refined foods, and fatty meats have increasingly replaced local foods. $†$ During this same period, nutrition-related disorders, including VAD and chronic diseases, have become serious problems and appear to be the consequence of dietary and lifestyle changes $^{27,28}$.

The underlying cause of VAD is a lack of vitamin A (VA) or provitamin A carotenoids ${ }^{29}$. White rice, flour and sugar contain neither of these nutrients, whereas local foods contain small amounts, but important in local diets ${ }^{30}$. Epidemiological evidence suggests that carotenoid-rich foods also have a protective role against chronic disease, including certain types of cancer, cardiovascular disease, diabetes and age-related macular degeneration ${ }^{31-33}$. Thus,

tLocal foods in this paper refer to foods that are grown, harvested, hunted or gathered from the land or sea. 
to understand better this apparently diet-related epidemiological transition, this paper looks at past and contemporary diets, in particular those local foods that may impact on VA and nutritional status.

\section{Methods}

The paper reviews all identified published and unpublished documents containing information related to food and nutrition in FSM up to October 2001. Government and locally available documents that are not normally available were reviewed, as were primary electronic sources. The analysis was organised around five key headings: historical background, local foods, infant and young child feeding, dietary assessment and nutritional status.

\section{Historical background}

Prior to the first recorded European discovery in 1529 of the islands now known as FSM, there are no written records ${ }^{5,34}$. Although there are few early records related to diet or nutritional status, reports from early visitors to the islands suggest that the people ate a variety of foods and appeared healthy ${ }^{5,19,34}$.

In the mid-1850s, newcomers brought new foods and cooking methods ${ }^{35}$ and, unfortunately, introduced new diseases ${ }^{18,36}$. This resulted in a great loss of lives. From 1885 to 1945 , three foreign powers colonised the islands: Spain, Germany ${ }^{5,34}$ and Japan ${ }^{5,8,37,38}$. During the Japanese tenure, rice was introduced as a staple food. After the Japanese surrendered at the end of World War II, the islands became a part of the Trust Territories of the Pacific Islands (TTPI) under United States' administration. Several health surveys ${ }^{20,39,40}$ were carried out, and a healthcare system based on modern biomedicine was established $^{41,42}$. However, US interest was mainly strategic and little economic improvement was seen ${ }^{5,43}$. In 1961, the United Nations criticised the USA for neglecting the islands $^{43}$, at which time development activities were greatly increased. Unfortunately, the programmes established were often inappropriate for small island communities.

One set of controversial programmes that greatly influenced FSM food habits was the United States Department of Agriculture (USDA) supplementary feeding programmes ${ }^{16,44-57}$. The programmes started in the 1960s, increased in the $1970 \mathrm{~s}^{46,51}$ and continued to the early 1990s. USDA surplus commodities, including rice and tinned foods, provided food for school lunches, needy families, the elderly and disaster relief ${ }^{46,49}$. In 1985, the school lunch programme (US\$ 5 million per annum) provided meals to 29000 people $330 \%$ of the entire population), 180 days per year ${ }^{47}$. Long-time FSM residents report that the big dietary shift to rice consumption was in the 1970s, following the initiation of the programmes in the 1960s, indicating that the programmes and dietary shift were related.

There were sharp criticisms related to these programmes causing increased dependency, new food tastes $^{47-51}$, and, according to some reports, malnutrition related to households selling produce to school lunch programmes and using the money to buy imported foods ${ }^{46,47}$. USDA foods such as canned vegetables were not always liked ${ }^{58}$. Requests for inclusion of acceptable local items in the programme, such as drinking coconuts, were often not accepted due to US regulations requiring foods such as milk ${ }^{49}$. Furthermore, the lack of baseline surveys made it difficult to evaluate effects ${ }^{45,46,49}$. A nutritional evaluation in 1987 stated that the food services programme in Micronesia appeared to be an extension of the programme in the USA, and that there were no clear objectives $^{53}$. In conclusion to this all, food habits were being shaped ${ }^{48,50}$. By the 1970 s rice had become a major staple in the islands, along with sugar and other refined and tinned foods.

Another US food-related programme (established 1985) was the Expanded Food and Nutrition Education Program $(\text { EFNEP })^{59}$. Although it had some positive achievements, messages were often US-oriented and culturally inappropriate $^{49}$, promoting US-type foods and food guides, and undermining efforts for promoting local foods ${ }^{60}$.

In 1986, Pohnpei, Kosrae, Chuuk and Yap joined to become a nation, signing a compact with the USA ${ }^{61}$ that provided significant funding and had a strong influence on the economy, food production and consumption, and health programmes. Agriculture polices were however inconsistent, espousing written plans for promoting subsistence local food production but with most development efforts focused on export crops $^{62,63}$.

Local foods were promoted as part of a Family Food Production and Nutrition programme, supported by the United Nations Children's Fund (UNICEF), and carried out in an intersectoral project involving the schools, health offices, agriculture departments and non-governmental groups in all four states ${ }^{58}$. This programme ran from 1984 to 1999 , and increased awareness of the importance of local foods. Yet the effect of this programme was small, in comparison with the other forces affecting the nation ${ }^{61}$.

\section{Local foods}

FSM has an extraordinary diversity of plants ${ }^{64}$, with a number of cultivars for each of the major food crops ${ }^{62,65}$. Apart from coconut, the major food crops are breadfruit, banana, giant swamp taro ${ }^{5-8,10-14,18,48}$ and pandanus $5,6,11-14$. Because of the importance of these food crops to the overall diet and their potential contribution to vitamin A intake, the review focuses on these. Some cultivars have a yellow edible portion, suggesting carotenoid content ${ }^{66}$, and yet few have been analysed. In 1998 and 1999, yellow banana and giant swamp taro 
Food and nutrition in Micronesia: literature review

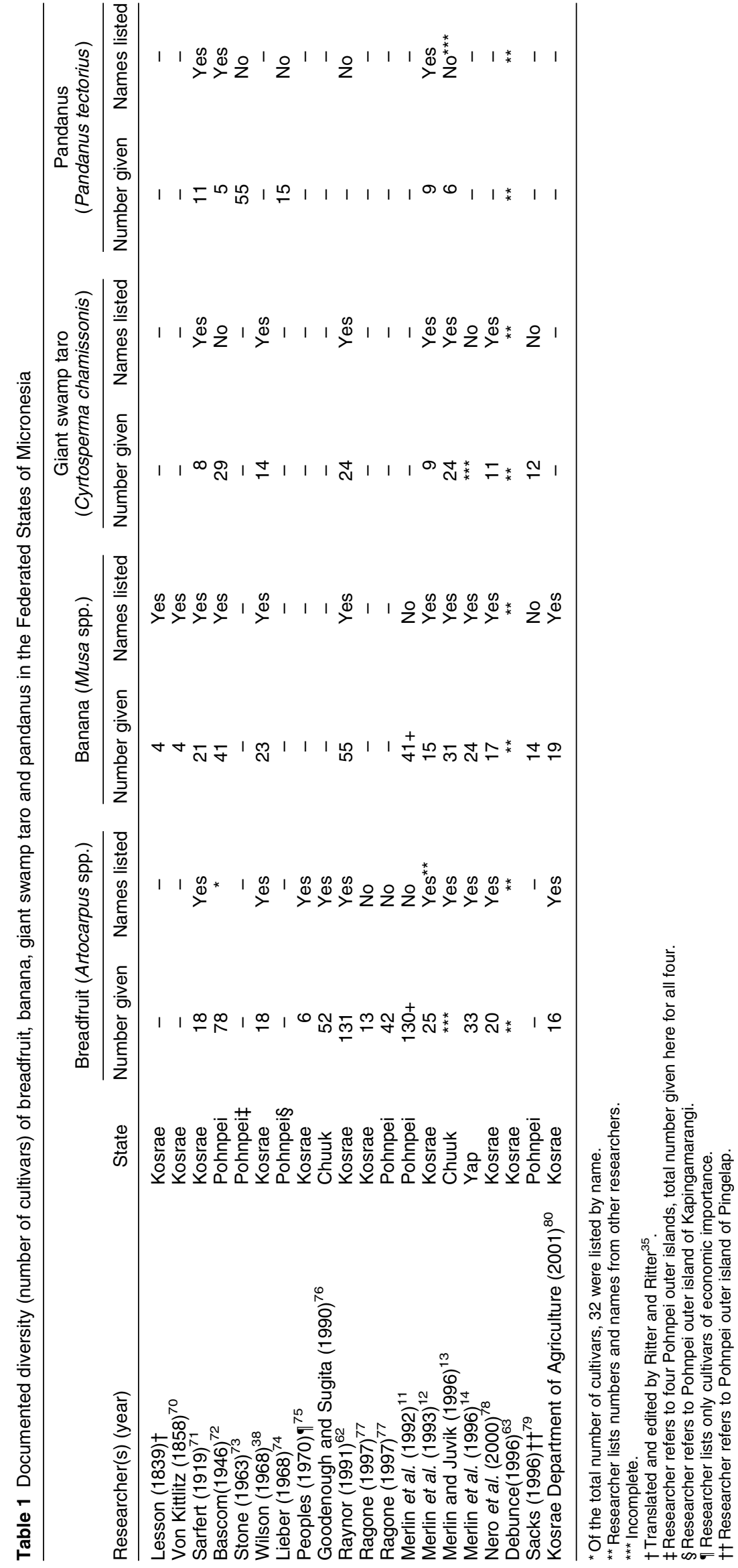


cultivars were found to contain significant amounts of provitamin A carotenoids ${ }^{67,68}$, suggesting that other yellow cultivars may also be carotenoid-rich. Pandanus was known to be VA-rich ${ }^{10,30,69}$. Table 1 summarises the number of cultivars of these staple foods and whether cultivar names were listed ${ }^{11-14,35,38,62,63,70-80}$.

\section{Breadfruit (Artocarpus spp.)}

Breadfruit is the traditional staple food most commonly eaten $^{5,6,10-14,77,81-83}$. In the past, breadfruit was baked or roasted in an earth oven ${ }^{71}$. Ripe seeded breadfruit can be eaten raw as a fruit. In recent times, breadfruit has also been boiled or fried ${ }^{5,63}$. Breadfruit is seasonal, with different cultivars bearing in succession. Preserved breadfruit $^{83}$ has provided food in times of need as well as between breadfruit seasons, and the fermented food, which is still well-liked by older people, provided variety in taste. The unseeded (Artocarpus altilis) and seeded (Artocarpus mariannensis) cultivars ${ }^{77}$ are important respectively for the volcanic and atoll islands ${ }^{84}$. Analyses of unseeded breadfruit indicate a low content of carotenoid $^{69,85}$, but that it is a good source of energy and dietary fibre, and a reasonable source of vitamin C. Seeds provide protein and thiamin ${ }^{4,30,86}$.

\section{Banana (Musa spp.)}

Banana has long been an important staple food $^{5-7,11-14,18,63}$. Certain cultivars were mentioned in early reports in the $1800 \mathrm{~s}^{12,87}$. Bananas are eaten raw as a fruit, and as a cooked part of the meal in a variety of recipes, either cooked alone or mixed with other starchy staples and coconut cream ${ }^{18,63}$. They are considered by some as a 'poor man's food", ${ }^{1,88}$. Bananas, and particularly karat banana, have also been important weaning foods ${ }^{89}$. Yet in recent years, this banana (now known to be VA-rich ${ }^{67,68}$ ) has become rare, along with a number of other local cultivars. Bananas are a good source of energy, vitamin $\mathrm{C}$, potassium and fibre ${ }^{4,30}$.

\section{Giant swamp taro (Cyrtosperma chamissonis)}

Giant swamp taro is commonly eaten throughout FSM and is the most important traditional food for Yap Y, $^{5,81,82,90}$ and the atoll islands ${ }^{90,91}$. It can be boiled or ground and baked with coconut cream or mashed banana in a number of recipes. Some cultivars were analysed for nutrient content and found to be low in provitamin A carotenoids ${ }^{30,92}$, but the yellow-fleshed cultivars were not analysed. Giant swamp taro grows in more saline soils, can remain in the soil for 10 years and still be edible, is not seasonal and endures hurricanes ${ }^{5,10,93}$, thus providing food security. It is a good source of energy, fibre and calcium ${ }^{4,30,86,94}$.

\section{Pandanus (Pandanus tectorius)}

Pandanus, many cultivars of which are known to be rich in vitamin $\mathrm{A}^{30,69,86,95,96}$, is another plant that can be grown in saline soils and is a major food on atoll islands ${ }^{93}$. The soft part of the pandanus key is chewed and sucked; on some islands, pandanus has been boiled for eating or dried for storage and made into flour for later cooking ${ }^{95}$. There have been as many as 19 cultivars on the atoll island Kapingamarangi ${ }^{73,74,97}, 14$ on Pingelap, 15 on Mokil $^{73,97}$ and 11 on $\mathrm{Kosrae}^{71}$, although little recognition was given to pandanus in recent agriculture work in Kosrae ${ }^{80}$. Pandanus is also a good source of vitamin C, thiamin, riboflavin and niacin $^{30,69,86}$.

\section{Otber foods}

Dark green leaves, a VA-rich food commonly eaten in other parts of the world, are regarded by many in FSM as pig food, similar to ripe papaya ${ }^{58,98}$. Green leafy vegetables including chilli pepper leaves, kangkong (Ipomoea aquatica), Chinese cabbage and two greens introduced in the $1990 \mathrm{~s}^{58}$, pele (Hibiscus manibot) and chaya (Cnidoscolus chayamansa), have been promoted, although with limited success ${ }^{58,98,99}$.

Contrary to common Western perceptions, the traditional Pacific diet did not include an abundance of different fruits. Papaya and mango, which are VA-rich if ripe $\mathrm{e}^{30,66,69,86}$, were introduced to Micronesia by Europeans in the 19th century $5,6,11-14,100$. Yet in FSM papaya and mango are commonly eaten green.

There are considerable differences in the names for foods according to state and island group. Although there is yet no compiled listing of all local names of FSM foods, there are some lists of food plants prepared by state $5,6,11-14,36,62,63,76,82$ and also a listing of food plants for the Pacific specifying some foods from FSM ${ }^{101}$.

Local animal foods include fish and other seafood ${ }^{50}$, which have been the major protein foods in the past. Raw fish liver, which is high in pre-formed $\mathrm{VA}^{29}$, is considered a delicacy $^{20}$, and some fish are eaten whole with the liver intact.

In summary, there is a great diversity of local foods, some which have potential for impact on VA status. Yet, the trends indicate that cultivar diversity, and knowledge, use and availability of local foods, are decreasing at an alarming rate ri-14,62,63,102. $^{11}$.

\section{Infant and young child feeding}

Infant and young child feeding is also an important part of the total food and nutrition situation. In the 1950s initiation of breast-feeding in FSM appeared to be almost universal, and it was common that mothers breast-fed children until the second year of life or later ${ }^{40,103}$. The situation had changed by the 1970s, with bottle feeding as a major factor in poor infant nutrition ${ }^{44,104,105}$.

An active breast-feeding campaign was started in the mid-1970s, and there appeared to be some increase in breast-feeding. However, although initiation of breastfeeding was high in the late 1980s (95\% of FSM infants were breast-fed in the first three months), duration was 
inadequate, with only $49 \%$ breast-fed at $12-17$ months and most not breast-fed at 18-23 months ${ }^{50}$. The Baby Friendly Hospital Initiative, supported by UNICEF and the World Health Organization (WHO), was introduced in the 1990s, providing greater support to breast-feeding ${ }^{106}$. Yet there is still a great lack of exclusive breast-feeding in the first six months of life, and duration of breast-feeding is still inadequate ${ }^{107}$

In the past, mothers did not give their breast (and colostrum) immediately to the newborn ${ }^{18,37,108}$, thinking that it was inadequate ${ }^{108}$. Young coconut water was given until the milk came in ${ }^{20}$; coconut oil lubricant was often given as the first feeding ${ }^{109}$. Breast-feeding was 'on demand', mothers sleeping with their babies so that nursing could continue through the night ${ }^{18}$. When mothers became pregnant or wanted early weaning, chilli pepper or breadfruit tree sap might be applied onto the breasts ${ }^{37}$. People believed that one could not breast-feed in pregnancy, as the milk became bad and could harm the child. Weaning was sometimes abrupt and was accomplished by sending the child to stay with relatives until the mother's milk dried up ${ }^{18}$. Sex taboos during lactation, extending until the child was around one year, were meant to ensure the health of the child and mother ${ }^{37,106,109,110}$, but may have led to an early termination of breast-feeding to allow resumption of sexual relations. In recent years the duration of this taboo has shortened ${ }^{110}$.

Solid foods have been given at an early age. In the 1980 s, $48 \%$ of infants were given these by four months of age $^{50}$. Local staple foods, often mashed banana or breadfruit, were common first foods, along with fruit, fruit juice and imported staples, including rice ${ }^{104}$. One problem identified in child feeding was that caretakers did not believe in the positive qualities of food related to health, and often did not encourage children to eat ${ }^{89}$. Pohnpei mothers believed that fish and meat should not be given until babies are 1 year old ${ }^{89}$, thinking either that they cause diarrhoea in babies or that these foods should be withheld to avoid the children getting used to them and becoming unhappy if they were unavailable ${ }^{110}$.

There have been numerous dietary taboos associated with pregnancy and the postpartum period ${ }^{110}$, including some foods such as fish, seafood and meat, which were thought to cause vomiting in pregnancy and difficult deliveries ${ }^{50}$. Similar foods were to be avoided during lactation for various reasons; for example eating octopus by a breast-feeding mother was thought to cause skin rash in the baby ${ }^{110}$. Foods encouraged during lactation were those made with coconut milk, as it was believed that these foods helped to make more breast milk. Mothers were also advised to drink water and other drinks as these were also believed to help make more breast milk ${ }^{110}$, and mothers were supported emotionally and not left alone ${ }^{109,110}$

Belief in the supernatural is a strong part of the Micronesian belief system $39,89,111-114$. Traditionally, people in FSM believed that spirits caused people to become sick if the people were in conflict $5^{5,114}$ and especially affected a child's well-being. People consider some illness treatable by Western medicine and other illnesses as those caused by spirits to be best treated by local medicine ${ }^{89,104}$. With strong beliefs in the supernatural, the relationship between food and health is not always well appreciated.

In summary, there have been many changes in infant and young child feeding practices in recent years. Campaigns promoting breast-feeding helped to curb the trend towards bottle feeding, although still there are problems with lack of exclusive breast-feeding, insufficient breast-feeding duration, and some other child feeding practices.

\section{Dietary assessment}

Only a few population-based dietary studies coupled with nutritional status assessments have been carried out in FSM. These include the 1987/88 FSM National Nutrition Survey $^{50}$, and in the year 2000 the Yap and Kosrae Micronutrients Survey ${ }^{115,116}$. However, smaller studies have been conducted that also help us understand the local diet ${ }^{40,44,50,63,78,89,103,115,117-120}$ (Table 2).

Four studies collected information on quantities of food eaten ${ }^{40,44,89,117}$. A review of the dietary assessments clearly showed an increasing reliance on rice, flour, sugar and imported meats. A low intake of VA-rich food was found, although previously it was not known that certain local staple foods contained high or moderate amounts of provitamin A carotenoids, which might have led to an underestimation of VA intake.

Dietary studies and papers since 1973 expressed concern over the increasing use of rice, sugar and flour, and poor food selection ${ }^{44,45,49,50,58,89,121}$. Rice was often the sole food for young children ${ }^{89}$. Health workers suggested that past feeding programmes based on rice, and expatriate buying patterns, helped lead to erroneous beliefs that rice and imported foods were superior to local foods ${ }^{48,121}$. That may no longer be the case. People appear to know now that local food is healthier, due to promotion programmes. Yet, rice, wheat flour and sugar foods are commonly eaten ${ }^{122}$ because of convenience, affordability, availability, taste and prestige $\mathrm{e}^{50,63}$.

In 1986, food and beverage imports accounted for more than $40 \%$ of the total value of imports. The same study reported that 'most of the items imported cannot be considered essential or without local substitutes in nutritional terms. Some may actually be nutritionally harmful ${ }^{47}$.

Common foods consumed in Pohnpei, Chuuk and Yap in the 1970s are presented in Table 3. Since then, rice has become the main starch food for many people ${ }^{63,106}$.

A recent assessment of the diet in Kosrae showed that local fish (reef and pelagic), imported chicken and turkey 


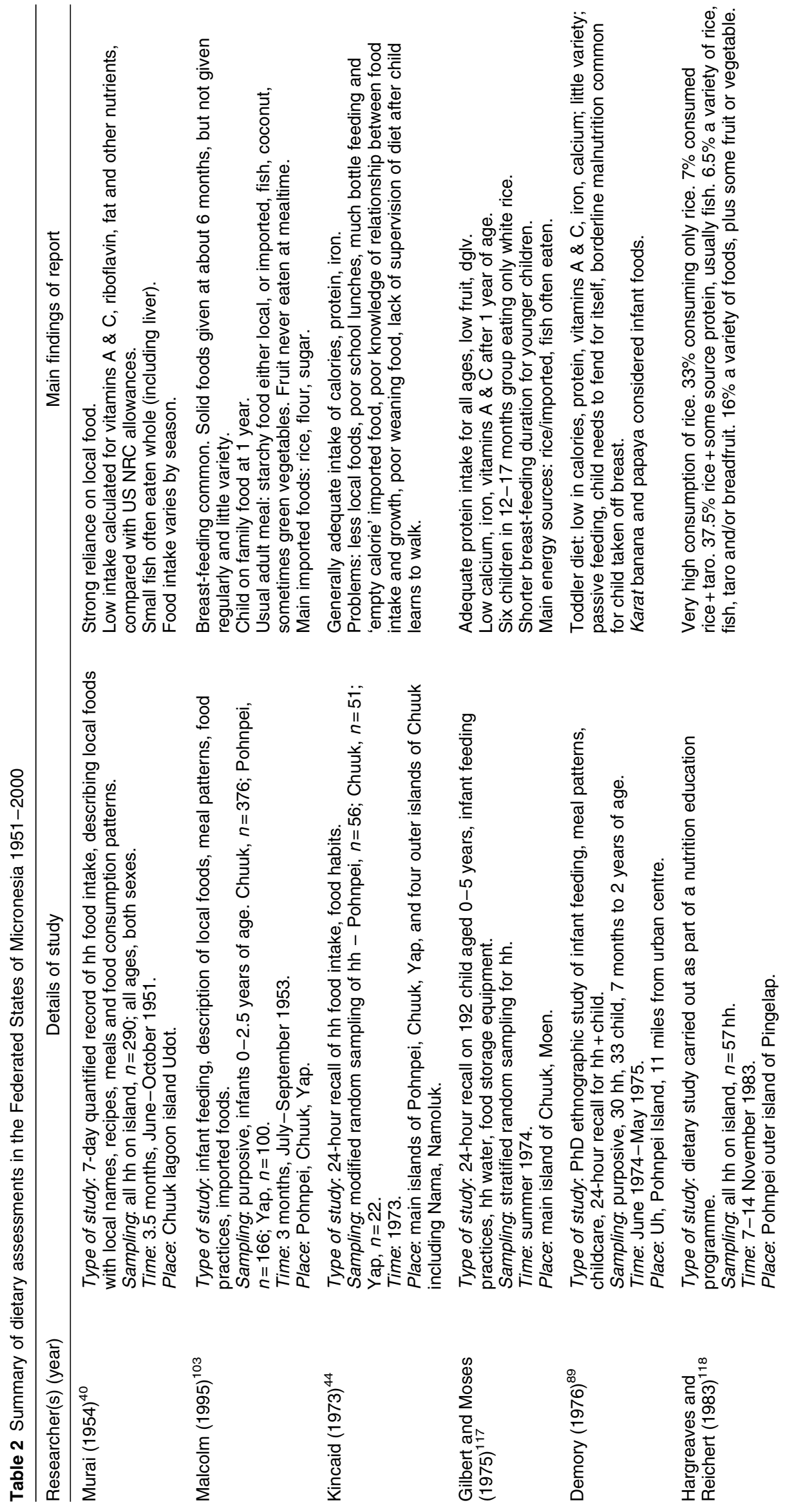




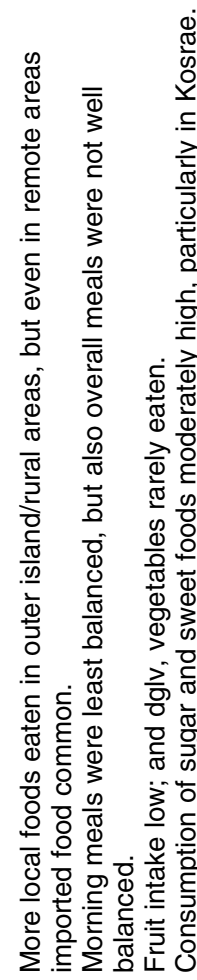

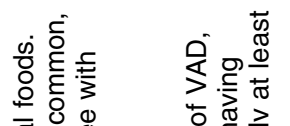

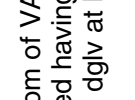

马

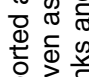

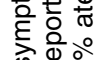

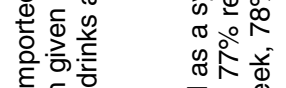

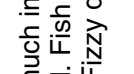

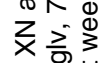

द्व

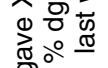

ه.

卷

它

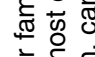

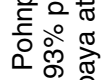

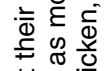

중

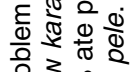

害. 过

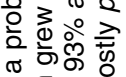

of 0

.

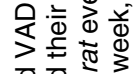

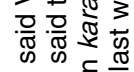

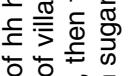

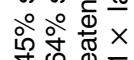

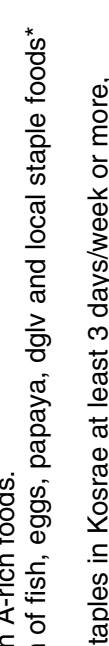

产 $\frac{\bar{c}}{\overline{\mathrm{C}}}$

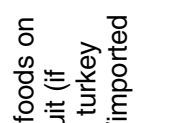

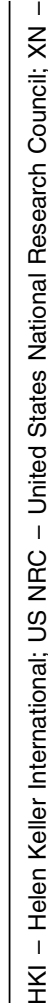

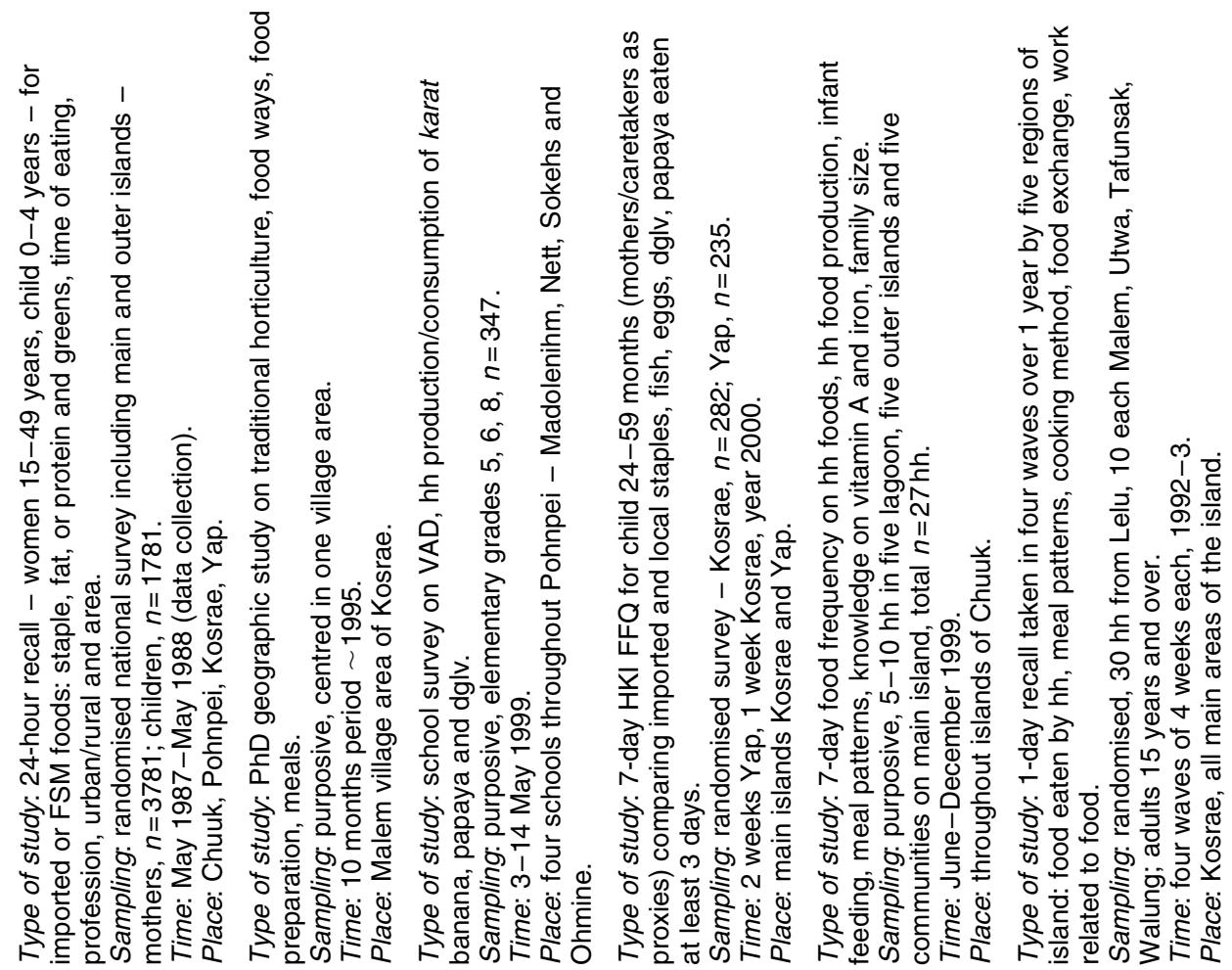

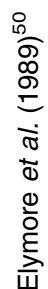

\begin{tabular}{l}
0 \\
0 \\
0 \\
8 \\
\hline \\
0 \\
0 \\
5 \\
0 \\
0 \\
0
\end{tabular}

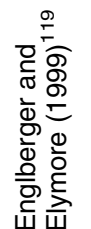

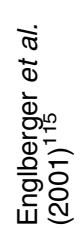

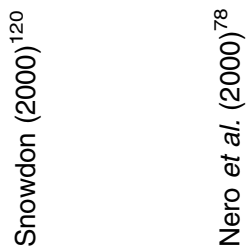

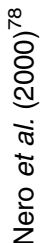

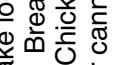

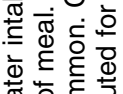

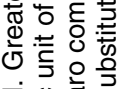

ธัँ

ब. $\frac{0}{0}$ क क

ह

ذ)

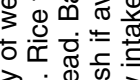

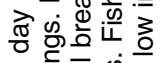

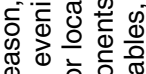

ه

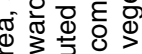

ब。워

वे क्षे

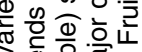

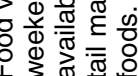

类 0

उ. 
tail are the major protein foods, and that consumption of canned fish increases when local fish are less available ${ }^{78}$. Turkey tail* (a fatty frozen product imported from the USA) is commonly eaten throughout $\mathrm{FSM}^{50,63,78,120}$. Turkey tail is another example of the replacement of healthy local foods with inferior food likely to cause health problems, which brings up the issue of food dumping by industrialised countries.

In summary, this section describes the great shift in the diet, with healthy local foods increasingly replaced by foods such as white rice, flour and sugar that contain no provitamin A carotenoids, and by other imported foods that are likely to cause health problems.

\section{Nutritional status}

This section focuses on vitamin A deficiency, anaemia, weights and heights of children, obesity, diabetes, hypertension in adults, and parasite infection.

\section{Vitamin A deficiency}

VAD in FSM was first documented in 1988 in a hospitalbased study in Chuuk ${ }^{123}$. Of 60 randomly selected 36-83month-old children, $12 \%$ were found with night blindness and 5\% with Bitot's spots, far exceeding WHO cut-offs for a public health problem, $1 \%$ and $0.5 \%$, respectively ${ }^{124}$. VAD was suggested to be a new problem, based on the lack of a local term for night blindness and old people in the community not knowing the problem. A 1991 statewide survey including 455 randomly selected children showed similar results ${ }^{125}$, and a 1994 study relating VAD with otitis media ${ }^{126}$ confirmed the problem. In 1992 a study of children aged 18-24 months and 3-6 years found that $55-76 \%$ of children surveyed had VAD as defined by levels of serum retinol $<20 \mu \mathrm{g} / \mathrm{dl}$, the prevalence varying depending on age group and with higher prevalence rates in older children ${ }^{127}$. VAD in Chuuk has been documented as among the most prevalent in the world ${ }^{124,128}$. In 1993, a VA supplementation and dietary improvement programme began $^{129,130}$.

In Pohnpei, a 1994 Child Health Survey looked at 24-47-month-old children. In that randomised population-based survey $(n=362) 51 \%$ of the children had $\mathrm{VAD}$, defined by serum retinol $<20 \mu \mathrm{g} / \mathrm{dl}^{131}$. Night blindness was reported for $0.3 \%$ of the children, under the cut-off level for a public health problem. A VA supplementation and dietary improvement programme began in Pohnpei in 1997, with promotion of VA-rich foods, including the karat banana (from 1999) ${ }^{132}$.

Due to concern about the remaining two FSM states, a population-based survey measuring serum retinol was carried out in January-February 2000 in Kosrae and the main island of Yap. Of the children aged 24-59 months

*Turkey tails are literally the tails of the turkeys. 
surveyed, 63.3\% in Kosrae and 33.8\% in Yap had VAD, defined by serum retinol $<20 \mu \mathrm{g} / \mathrm{dl}^{116}$; caretakers were asked if their children had experienced night blindness, and no such case was found although there were no visual evaluations. Some Kosrae mothers reported night blindness in the last pregnancy, although questioning was difficult due to the lack of terminology and understanding of night blindness. Serum retinol measurements were taken on mothers and caretakers. Of the women surveyed, $58 \%$ in Kosrae and $11.7 \%$ in Yap had VAD, defined by a serum retinol $<30 \mu \mathrm{g} / \mathrm{dl}^{133}$, which is a matter of concern particularly in light of the new evidence linking night blindness in pregnancy with increased mortality ${ }^{134}$.

\section{Anaemia}

In the FSM National Nutrition Survey, high rates of mild to moderate anaemia were found in the women studied (1549 years) in all states, with a greater problem in Kosrae where $37.6 \%$ of non-pregnant, non-lactating women had a haemoglobin measurement $<12 \mathrm{~g} / \mathrm{dl}^{50}$. The 1994 Pohnpei Child Health Study found 33\% of children were anaemic, with anaemia defined as haemoglobin $<11.5 \mathrm{~g} / \mathrm{dl}$. However, anaemia rates in children examined in Yap and Kosrae were $12.6 \%$ and $9.8 \%$, respectively, with anaemia defined as haemoglobin $<11.0 \mathrm{~g} / \mathrm{dl}$ measured by the portable HemoCue ${ }^{\mathrm{TM}}$ instrument ${ }^{116}$. These rates are relatively low given that rates of anaemia are often more than $50 \%$ in many communities in developing countries $^{135}$, and anaemia tends to be high in populations with high rates of $\mathrm{VAD}^{29}$.

\section{Weights and beights of children}

The 1987/88 FSM National Nutrition Survey found that, overall, among children $0-4$ years old, there were $9.9 \%$ stunted and $13.3 \%$ underweight $(<80 \%$ of WHO/National Center for Health Statistics standards). In the Yap and Kosrae study in 2000, $17.1 \%$ and $16.2 \%$ of children were stunted, respectively. Wasting in both populations was less than 5\%. Stunting and wasting were defined as $<2$ standard deviations below WHO/Centers for Disease Control and Prevention standards for height-for-age and weight-for-height, respectively. These reports can be compared with the WHO proposed classification of worldwide prevalence of low stunting and wasting among children $<5$ years of age, which are $<20 \%$ and $<10 \%$, respectively ${ }^{136}$.

\section{Obesity, diabetes and bypertension in adults}

Obesity, diabetes and hypertension are now serious problems in FSM. In the 1987/88 FSM National Nutrition Survey $^{50}$, the weights and heights of 3588 women (15-49 years) were measured, finding a mean body mass index (BMI) of $28 \mathrm{~kg} \mathrm{~m}^{-2}$. Approximately one-third of all women were moderately overweight in every age group, with overweight defined as BMI $\geq 25$ and $<30 \mathrm{~kg} \mathrm{~m}^{-2}$. Prevalence of obesity (defined as BMI $\geq 30 \mathrm{~kg} \mathrm{~m}^{-2}$ ) was particularly high in Kosrae (77\%) in those aged 40-49 years. The Non-Communicable Disease (NCD) study carried out in 1992-94 examined over 4500 adults in all FSM states, and preliminary analyses found high prevalences of obesity, hypertension, diabetes and dyslipidaemia. A further analysis focusing on Kosrae data $^{137}$ indicated that of 1259 females and 908 males examined, $24 \%$ were obese (defined as BMI $\geq 35 \mathrm{~kg} \mathrm{~m}^{-2}$ ), with average BMI of $31 \mathrm{~kg} \mathrm{~m}^{-2}$. This BMI, exceeding the WHO Grade 2 overweight cut-off ${ }^{136}$, and the other obesity levels is of concern. Hypertension (systolic blood pressure $\geq 140 \mathrm{mmHg}$ or diastolic blood pressure $\geq 90 \mathrm{mmHg}$ ) was found among $17 \%$ of those surveyed and $12 \%$ qualified as diabetic (fasting blood sugar $\geq 126 \mathrm{mg} / \mathrm{dl}$ or 2 -hour oral glucose tolerance test $\geq 200 \mathrm{mg} / \mathrm{dl}$ ). The highest risk for obesity was in middle age. There seemed to have been little problem with hypertension in former times, with blood pressures low in Pohnpeians in the late $1940 \mathrm{~s}^{25}$. A 1970 study found increasing diastolic and systolic pressures with increasing modernity ${ }^{26}$.

\section{Parasite infection}

Parasite infection has a great effect on nutritional status and health and has been a serious problem in $\mathrm{FSM}^{20,27,39,89}$. In Kapingamarangi in $1953,36.4 \%$ of those 275 people examined had at least one parasite ${ }^{20}$. In 1975 one-third of all hospitalised children had intestinal parasites $^{27}$. With sanitation improvements, parasite infection has been reduced in recent years, although there are few data available. Along with VA supplementation in Chuuk and Pohnpei, all children from 1 to 12 years are now treated for parasite infection twice annually ${ }^{130}$.

In summary, although parasite and infectious disease have decreased in FSM in recent years, the emergence of vitamin A deficiency, obesity, hypertension and diabetes are serious concerns.

\section{Conclusions}

This review brings together, for the first time, a diverse body of data on food and nutrition for FSM. This shows that nutritional status prior to European contact was apparently good, and there was a diversity of local staple foods. The data available indicate that these foods contain at least minimal amounts of carotenoids, and some have high levels ${ }^{67}$, important for protection against VAD and apparently against certain types of cancer, cardiovascular disease, diabetes and age-related macular degeneration. The replacement of local foods with foods such as white rice, flour and sugar, which contain no $\mathrm{VA}^{30}$, and increased use of breast-milk substitutes, is a matter of concern particularly in relation to child health.

The great changes in diets and infant feeding practices in the 1970s, which preceded the apparent emergence of $\mathrm{VAD}$ in the 1980s, appear to be a main causal component in the present-day nutrition problems. The coherence and 
consistency of the collection of studies provide a basis for arguing that the dietary and lifestyle changes are in fact largely responsible for the present-day VAD and chronic diseases problem. Inconsistent external and internal government policies and food aid programmes contributed to the dietary changes.

The review indicates that there is a need for further research into the nutritional content of local foods and underlying factors affecting their consumption, as well as information on dietary intake. Such information is essential in understanding better how and when local foods could be realistically and reasonably promoted to contribute to improved nutritional status. Finally, this review indicates that local foods have been important in the past in maintaining the health of FSM people. Serious consideration should be given to the establishment of a broad, well-planned, intersectoral intervention aimed at increasing the production and consumption of local foods and dietary improvement for all population age groups.

\section{Acknowledgements}

Acknowledgement is given to Fran Hezel and Jane Paterson for reviewing the original manuscript, and to Task Force Sight and Life, Centers for Disease Control and Prevention and Thrasher Research Fund for funding support.

\section{References}

1 Federated States of Micronesia. A Situation Analysis of Children and Women in the Federated States of Micronesia. Suva, Fiji: United Nations Children's Fund (UNICEF) Pacific, 1996.

2 Federated States of Micronesia (FSM) Department of Economic Affairs. Preliminary Counts. 2000 FSM-wide Census of Population and Housing. Palikir, Pohnpei: FSM Government, 2002.

3 Winter SJ, Campbell BL. Water Supply for Remote Tropical Islands: A High School Teaching Supplement. Mangilao, Guam: Water and Energy Research Institute, University of Guam, 1995.

4 Secretariat of the Pacific Community. The Staples We Eat. Noumea, New Caledonia: Secretariat of the Pacific Community, 1999.

5 Fischer JL, Fischer AM. The Eastern Carolines. Behavioral Science Monographs. New Haven, CT: Pacific Science Board, National Academy of Sciences-National Research Council in association with Human Relations Area Files, 1957.

6 Bascom WR. A Pacific Economy in Transition. Vol. 22. Berkeley, CA: University of California Press, 1965.

7 Petersen GT. Ponapean agriculture and economy: politics, prestige and problems of commercialization in the Eastern Caroline Islands. Ph.D thesis, Columbia University, New York, 1976.

8 Labby D. The Demystification of Yap: Dialectics of Culture on a Micronesian Island. Chicago, IL: University of Chicago Press, 1976.

9 Damas D. Bountiful Island: A Study of Land Tenure on a Micronesian Atoll. Waterloo, Ontario: Wilfrid Laurier University Press, 1994
10 Pollock NJ. These Roots Remain: Food Habits in Islands of the Central and Eastern Pacific since Western Contact. Laie, HI: The Institute for Polynesian Studies, 1992.

11 Merlin M, Jano D, Raynor W, Keene T, Juvik J, Sebastian B. Tubke en Pohnpei: Plants of Pohnpei. Honolulu, HI: EastWest Center, 1992.

12 Merlin M, Taulung R, Juvik J. Sabk Kap Ac Kain In Acn Kosrae: Plants and Environments of Kosrae. Honolulu, HI: East-West Center, 1993

13 Merlin M, Juvik J. Ira me Neeniier non Chuuk: Plants and their Environments in Chuuk. Honolulu, HI: East-West Center, 1996.

14 Merlin M, Kugfas A, Keene T, Juvik J. Gidii nge Gakiiy nu Wa'ab: Plants, People and Ecology in Yap. Honolulu, HI: East-West Center, 1996.

15 Parkinson S. Nutrition in the South Pacific - past and present. J. Food Nutr. 1982; 39(3): 121-5.

16 Thaman RR. Deterioration of traditional food systems, increasing malnutrition and food dependency in the Pacific Islands. J. Food Nutr. 1982; 39(3): 109-21.

17 Coyne T, Badcock J, Taylor R. The Effect of Urbanisation and Western Diet on the Health of Pacific Island Populations. SPC Technical Paper No. 186. Noumea, New Caledonia: South Pacific Commission, 1984.

18 Ritter PL. The repopulation of Kosrae: population and social organization on a Micronesian bigh island. Ph.D thesis, Stanford University, Stanford, CA, 1978.

19 O'Connell JF. A Residence of Eleven Years in New Holland and the Caroline Islands. Honolulu, HI: The University Press of Hawaii, 1972.

20 Miller RE. 20. Health report of Kapingamarangi. Atoll Research Bulletin. Washington, DC: The Pacific Science Board, National Academy of Sciences-National Research Council, 1953; 19-23.

21 Christian FW. The Caroline Islands: Travel in the Sea of the Little Lands. London: Frank Cass \& Co. Ltd, 1899.

22 Denfield DC. Field Survey of Ponape: World War II Features. Micronesian Archaeological Survey Reports No. 2. Saipan, Northern Mariana Islands: Office of Historic Preservation, Trust Territory of the Pacific Islands, 1979.

23 Richard DE. United States Naval Administration of the Trust Territory of the Pacific Islands. Vol. II. Washington, DC: Office of the Chief of Naval Operations, 1957.

24 Brown JM. Peoples \& Problems of the Pacific. London: J.H. Sears \& Company, Inc., 1927.

25 Murrill RI. A blood pressure study of the natives of Ponape Island, Eastern Carolines. Hum. Biol. 1949; 21: 47-59.

26 Patrick RC, Prior IAM, Smith JC, Smith AH. Relationship between blood pressure and modernity among Ponapeans. Int. J. Epidemiol. 1983; 12(1): 36-44.

27 Rody N. Things go better with coconuts - program strategies in Micronesia. J. Nutr. Educ. 1978; 10(1): 19-22.

28 Flear J. Good intentions: good enough? Observations of the sociocultural aspects of health care delivery in Micronesia. Presented at the Institutes of Medicine Meeting, Saipan, Commonwealth of the Northern Mariana Islands, 18-19 April 1997.

29 McLaren DS, Frigg M. Sight and Life Manual on Vitamin A Deficiency Disorders (VADD), 2nd ed. Basel: Task Force Sight and Life, 2001.

30 Dignan CA, Burlingame BA, Arthur JM, Quigley RJ, Milligan GC. The Pacific Islands Food Composition Tables. Noumea, New Caledonia: South Pacific Commission, 1994.

31 World Cancer Research Fund. Food, Nutrition and the Prevention of Cancer: A Global Perspective. Washington, DC: American Institute for Cancer Research, 1997.

32 Bertram JS, ed. Proceedings of the 13th International Carotenoid Symposium, Honolulu, Hawaii, 6-11 January 2002. Pure and Applied Chemistry, 2002 [in press].

33 Mares-Perlman JA, Millen AE, Ficek TL, Hankinson SE. The 
body of evidence to support a protective role for lutein and zeaxanthin in delaying chronic disease. Overview. J. Nutr. 2002; 132(3): 518S-24S.

34 Hezel FX, Berg ML, eds. Micronesia Winds of Change: A Book of Readings on Micronesian History. Saipan, Northern Mariana Islands: Trust Territories of the Pacific Islands Printing Press, 1980.

35 Ritter LT, Ritter PL, eds. The European Discovery of Kosrae Island: Accounts by Louis Isidore Duperrey, Jules Sebastien Cesar Dumont D'Urville, Rene Primevere Lesson, Fyedor Luetke and Friedrich Heinrich von Kittlitz. Micronesian Archaeological Survey Report No. 13. Saipan, Commonwealth of the Northern Mariana Islands: Office of Historic Preservation, Office of the High Commissioner, Trust Territories of the Pacific Islands, 1982.

36 Segal HG. Kosrae: The Sleeping Lady Awakens. Kosrae, Federated States of Micronesia: Kosrae State Tourist Division, Department of Conservation and Development, Kosrae State Government, 1989.

37 Fischer A. The Role of the Trukese Mother and Its Effect on Child Training. Scientific Investigation of Micronesia Report 8. Washington, DC: Pacific Science Board of the National Research Council, 1957.

38 Wilson WS. Land, activity and social organization of Lelu, Kusaie. Ph.D thesis, University of Pennsylvania, Philadelphia, PA, 1968.

39 Richard DE. United States Naval Administration of the Trust Territory of the Pacific Islands. Vol. III. The Trusteeship Period 1947-1951. Washington DC: Office of the Chief of Naval Operations, 1957.

40 Murai M. Nutrition study in Micronesia. Atoll Research Bulletin. Washington, DC: The Pacific Science Board, National Academy of Sciences-National Research Council, 1954; 27.

41 Ballendorf DA. German Micronesia and the beginning of medical and health education. Pac. Health Dialog 1994; 1(1): 24-5.

42 Hezel FX. Strangers in Their Own Land: A Century of Colonial Rule in the Caroline and Marshall Islands. Honolulu, HI: University of Hawaii Press, 1995.

43 Kiste RC, Marshall M. American anthropology in Micronesia, 1941-1997. Pac. Sci. 2000; 54(3): 265-74

44 Kincaid PJ. Trust Territory of the Pacific Islands Nutrition Survey. Saipan, Northern Mariana Islands: Department of Health Services, Trust Territories of the Pacific Islands, 1973

45 Rody N. Food for all in Micronesia. Pac. Mag. 1982; (September/October): 27-30.

46 Rody N. Empowerment as organizational policy in nutrition intervention programs: a case study from the Pacific Islands. J. Nutr. Educ. 1988; 20(3): 133-41.

47 Cameron J. A Report on Economic Policies for Achieving Greater Food Self-sufficiency and Improved Nutrition in the Federated States of Micronesia at National Level and in the States of Pohnpei and Truk. FAO/UNDP Project, Development of National Food and Nutrition Planning Program in the South Pacific. Palikir, Pohnpei, 1986.

48 Ward MC. Nest in the Wind. Perspective Heights, IL: Waveland Press, Inc., 1989.

49 Schoeffel P. Food, health, and development in the Pacific islands: policy implications for Micronesia. ISLA: J. Micronesian Studies 1992; 1(2): 223-50.

50 Elymore J, Elymore A, Badcock J, Bach F, Terrell-Perica S. The 1987/1987 National Nutrition Survey of the Federated States of Micronesia. Technical report prepared for the Government and Department of Human Resources of the FSM. Noumea, New Caledonia: South Pacific Commission, 1989

51 Severance CJ. From atoll to federal agency: the politics of feeding people. In: Hurd JN, ed. The Emerging Pacific
Island States. Proceedings of the Fourth Annual Pacific Islands Studies Conference, University of Hawaii at Manoa, 6- 7 April 1979. Miscellaneous Work Papers. Honolulu, HI: University of Hawaii, 1979; 27-35.

52 Severance CJ. Food for Piis: interests, linkages and the impact of federal feeding programs on a peripheral atoll. Presented at Symposium on Dependency and Development in Oceania at 9th Annual Meeting of the Association for Social Anthropology in Oceania, Galveston, TX, 26 February-2 March 1980.

53 Singleton N. A Nutritional Assessment of the Food Services Program. Consultant to DP/RAS/87/015. Development of National Food and Nutrition Planning and Program in the South Pacific. Food and Agriculture Organization of the United Nations. Palikir, Pohnpei, 1987.

54 Borthwick M. A role for anthropology in Micronesian social program development. Presentation at ASAO Special Session: The Role of Anthropology in Contemporary Micronesia, Monterey, CA, 15-19 February 1978.

55 Marshall M. Natural and unnatural disaster in the Mortlock Islands of Micronesia. Hum. Org. 1979; 38(3): 265-72.

56 Denman VM, Dewey KG. Food self-sufficiency in Micronesia: effects of a nutrition assistance programme on food consumption. Food Policy 1989; 14(4): 330-46.

57 Denman VM, Dewey KG. Food self-sufficiency in Micronesia: effects of a nutrition assistance programme on agricultural production. Food Policy 1992; 17(3): 174-86.

58 Schoeffel P, Bolabola C, Noirmidol C. The UNICEF Family Food Production and Nutrition Project. Evaluation Report. DSIR Social Science, Ilam Research Centre, Christchurch, New Zealand, 1991.

59 College of Micronesia Cooperative Extension Service. Expanded Food and Nutrition Educational Program. Kolonia, Pohnpei, Federated States of Micronesia, 1994.

60 Federated States of Micronesia (FSM) Department of Health. National Plan of Action for Nutrition. 2000-2005. Palikir, Pohnpei: FSM Government, 1999.

61 Federated States of Micronesia (FSM) National Advisory Council on Children. Federated States of Micronesia. Two Years Implementation on the United Nations Convention on the Rights of the Child. Palikir, Pohnpei: FSM Government, 1996.

62 Raynor B. Agroforestry Systems in Pohnpei - Practices and Strategies for Development: RAS/86/036 Field Document 4. FAO/UNDP South Pacific Forestry Development Programme, 1991.

63 Debunce LA. Cultural changes in horticultural practices on the high island of Kosrae, Micronesia. Ph.D. thesis, University of Oregon, Eugene, OR, 1996.

64 Balick MJ, Raynor B, Lee R. Ethnobotany of the Federated States of Micronesia: An Integrative Approach to Understanding, Preserving, Utilizing and Teaching Traditional Knowledge in the Pacific Region. Project proposal. Kolonia, Pohnpei, Federated States of Micronesia: The New York Botanical Garden, The Nature Conservancy and Program of Integrative Medicine, University of Arizona, 1999.

65 Raynor B, Lorens A, Phillip J. Traditional yam cultivation on Pohnpei, Eastern Caroline Islands, Micronesia. Econ. Bot. 1992; 46(1): 25-33.

66 Rodriguez-Amaya DB. Carotenoids and Food Preparation: The Retention of Provitamin A Carotenoids in Prepared, Processed, and Stored Foods. Arlington, VA: USAID OMNI Project, 1997.

67 Englberger L. Natural food sources of provitamin A that have previously been unrecognized [letter to the editor]. Food Nutr. Bull. 2001; 22(1): 99-101.

68 Shovic AC, Whistler WA. Food sources of provitamin A and vitamin C in the American Pacific. Trop. Sci. 2001; 41(4): 199-202.

69 Murai M, Pen F, Miller CD. Some Tropical South Pacific 
Island Foods. Description, History, Use, Composition, and Nutritive Value. Honolulu, HI: University of Hawaii Press, 1958.

70 von Kittlitz FH. Denkwuerdigkeiten einer Reise nach dem russischen Amerika, nach Mikronesien, und durch Kamtschatka. Gotha: Verlag von Justus Berthea, 1858.

71 Sarfert E. Hamburgische Wissenschaftliche Stiftung: Ergebnisse der Suedsee-Expedition 1908-1910. Herausgegeben von Prof. Dr. G. Thilenius. II. Ethnographie: B. Mikronesien Band 4. Kusae 1. Halbband. Hamburg: L. Friederichsen \& Co., 1919.

72 Bascom WH. Ponape: A Pacific Economy in Transition. Vol. 8. Honolulu, HI: US Commercial Company, Economic Survey of Micronesia, 1946.

73 Stone BC. The role of pandanus in the culture of the Marshall Islands. In: Barrau J, ed. Plants and the Migrations of Pacific Peoples: A Symposium. Honolulu, HI: Bishop Museum Press, 1963.

74 Lieber MD. Porakiet: A Kapingamarangi colony on Ponape. Ph.D. thesis, Department of Anthropology, University of Oregon, Eugene, OR, 1968.

75 Peoples JG. Deculturation and dependence in a Micronesian community. Ph.D. thesis, University of California, Santa Cruz, CA, 1970.

76 Goodenough WH, Sugita H. Trukese-English Dictionary. Supplementary Volume: English Trukese and Index of Trukese Word Roots. Philadelphia, PA: American Philosophical Society, 1990.

77 Ragone D. Breadfruit Artocarpus altilis (Parkinson) Fosberg: Promoting the Conservation and Use of Underutilized and Neglected Crops, 10. Rome, Italy: International Plant Genetic Resources Institute, 1997.

78 Nero KL, Burton ML, Jonas M, Taulung S. Kubpi: Kosrae State Food Systems Study 1992-3, Federated States of Micronesia. Preliminary Report. Tofol, Kosrae, Federated States of Micronesia: University of California, Irvine, Kosrae State Government, Department of Planning and Statistics, Department of Resources and Development, The University of Auckland, 2000.

79 Sacks O. The Island of the Colorblind. New York: Vintage Books, 1996.

80 Kosrae Department of Agriculture. State Fair Results by Weight and Length. Tofol, Kosrae: Kosrae State Government, 2001.

81 Egan JA. Taro, fish, and funerals: transformations in the Yapese cultural topography of wealth. Ph.D. thesis, University of California, Irvine, CA, 1998.

82 Falanruw MVC. The Yapese agricultural system. Ph.D. thesis, University of the South Pacific, Suva, Fiji, 1995.

83 Ayres WS, Mauricio R. Micronesian Resources Study Pohnpei Archaeology Component. Salapwuk Archaeology: A Survey of Historic and Cultural Resources on Pohnpei, Federated States of Micronesia. San Francisco, CA: Micronesian Endowment for Historic Preservation, Federated States of Micronesia, and US National Park Service, 1997.

84 Tilfas R, Tolenoa A. Legends of Kosrae. Tofol, Kosrae: Curriculum Division, Kosrae Education Department, Kosrae State Government, Federated States of Micronesia, 1993.

85 Aalbersberg WGL, Lovelace CEA, Madhoji K, Parkinson SV. Davuke, the traditional Fijian method of pit preservation of staple carbohydrate foods. Ecol. Food Nutr. 1988; 21: 173-80.

86 Peters FE. The Chemical Composition of South Pacific Foods. Technical Paper No. 115. Noumea, New Caledonia: South Pacific Commission, 1958.

87 von Kittlitz FH, Twenty-four Views of the Vegetation of the Coasts and Islands of the Pacific with Explanatory Descriptions Taken During the Exploring Voyage of the
Russian Corvette Senjawis under the command of Capt Lutke in the year 1827, 1828, and 1829. Translated from the German by Berthold Seemann. London: Longman, 1861.

88 Peoples JG. Island in Trust: Culture Change and Dependence in a Micronesian Economy. Boulder, CO: Westview Press, 1985.

89 Demory BGH. An illusion of surplus: the effect of status rivalry upon family consumption. Ph.D. thesis, University of California, Berkeley, CA, 1976.

90 Mahoney F. Taro cultivation in Truk. In: Young JE, ed. Taro Cultivation Practices and Beliefs: Part II. The Eastern Carolines and the Marshall Islands. Anthropological Working Paper No. 6. Guam: Trust Territory of the Pacific Islands, 1960.

91 Mahoney F. Taro cultivation in Ponape. In: Young JE, ed. Taro Cultivation Practices and Beliefs: Part II. The Eastern Carolines and the Marshall Islands. Anthropological Working Paper No. 6. Guam: Trust Territory of the Pacific Islands, 1960.

92 Bradbury JH, Holloway WD. Chemistry of Tropical Root Crops: Significance for Nutrition and Agriculture in the Pacific. Canberra: Australian Centre for International Agricultural Research, 1988.

93 Oliver DL. Oceania: The Native Cultures of Australia and the Pacific Islands. Vol. I. Honolulu, HI: University of Hawaii Press, 1989.

94 Community Education Training Centre. Taro: South Pacific Foods Revised Leaflet \# 1. Noumea, New Caledonia: South Pacific Commission, 1992.

95 Miller CD. The use of pandanus fruit as food in Micronesia. Pac. Sci. 1956; 10(1): 3-16.

96 Hiyane JT. Pandanus in the Marshall Islands. Agriculture Extension Bulletin No. 10 Trust Territory of the Pacific Islands. Sydney: Bridge Printery Ltd, 1971.

97 Stone BC. The genus Pandanus in Micronesia I. The Marianas species. Micronesia 1967; 3(2): 105-21.

98 Thomas P. Report on the Communication Requirements of the Pohnpei Food and Nutrition Council. Kolonia, Pohnpei: Pohnpei State Department of Health, 1988.

99 Kuwabara Y. Dietary Improvement and Health Developments Programs in Pohnpei State, in the Federated States of Micronesia: Generalization Report 1998-2000. Pohnpei, FSM: Japan Overseas Cooperation Volunteers, 2000.

100 Lewis N. The history and culture of food and drink in subSaharan Africa and Oceania: the Pacific Islands. In: Kiple $\mathrm{KF}$, Ornelas KC, eds. The Cambridge World History of Food. Cambridge: Cambridge University Press, 2000; 1351-66.

101 Jardin C. Kulu, Kuru, Uru: Lexicon of names of food plants in the South Pacific. Lexique des noms de plantes alimentares dans le Pacifique Sud. Noumea, New Caledonia: South Pacific Commission, 1974.

102 Lee RA, Balick MJ, Ling DL, Sohl F, Brosi BJ, Raynor W. Cultural dynamism and change - an example from the Federated States of Micronesia. Econ. Bot. 2001; 55(1): 9-13.

103 Malcolm S. Diet and Nutrition in the Trust Territory of the Pacific Islands. Technical Paper No. 83. Noumea, New Caledonia: South Pacific Commission, 1955.

104 Marshall LB, Marshall M. Infant feeding and infant illness in a Micronesian village. Soc. Sci. Med. 1980; 148: 33-8.

105 Marshall LB, Marshall M. Breasts, bottles and babies: historical changes in infant feeding practices in a Micronesian village. Ecol. Food Nutr. 1979; 8: 241-9.

106 Hezel FX. The New Shape of Old Island Cultures: A Half Century of Social Change in Micronesia. Honolulu, HI: University of Hawaii Press, 2001.

107 Englberger L, Elymore J. Federated States of Micronesia World Breastfeeding Week Report. Palikir, Pohnpei: FSM Department of Health, Education, and Social Affairs, 1999. 
108 Thomas MD. Transmitting culture to children on Namonuito Atoll, Caroline Islands. Ph.D. thesis, University of Hawaii, Honolulu, HI, 1978.

109 Ashby G. Some Things of Value: Micronesian Customs and Beliefs. Eugene, OR: Rainy Day Press, 1985.

110 Fitzgerald MH. Whisper of the Mother: From Menarche to Menopause among Women in Pohnpei. Westport, CT: Greenwood Publishing Group, Inc., 2001.

111 Mahoney FJ. A Trukese theory of medicine. Ph.D. thesis, Stanford University, Stanford, CA, 1969.

112 Ward RL. Curing on Ponape: a medical ethnography. Ph.D. thesis, Tulane University, New Orleans, LA, 1977.

113 Rubinstein DH. Staking ground: medical anthropology, health, and medical services in Micronesia. In: Kiste RC, Marshall M, eds. American Anthropology in Micronesia: An Assessment. Honolulu, HI: University of Hawaii Press, 1999.

114 Close Up Foundation. Micronesia: A Guide Through the Centuries. Alexandria, VA: Close Up Foundation, 2000.

115 Englberger L, Elymore J, Sowell A, Gonzaga PS, Huff D. Dietary intake of vitamin A in preschool children in Yap and Kosrae States, Micronesia [abstract]. In: Proceedings of XX International Vitamin A Consultative Group Meeting, Hanoi, Viet Nam, 12-15 February 2001. Washington, DC: ILSI Research Foundation, 2001; 39.

116 Centers for Disease Control and Prevention. Vitamin A deficiency among children - Federated States of Micronesia, 2000. Morbidity Mortality Weekly Rep. 2001; 50(24): 509-12.

117 Gilbert D, Moses E. Truk Nutrition Survey, Summer 1974. Report prepared for International Health Program, School of Public Health. Honolulu, HI: University of Hawaii, 1975.

118 Hargreaves LJ, Reichert E. Pingelap Nutrition Study. Kolonia, Pohnpei, Federated States of Micronesia: Pacific Missionary Aviation, 1983.

119 Englberger L, Elymore J. Federated States of Micronesia Vitamin A Program 1998-1999, Palakir, Pohnpei, Federated States of Micronesia (FSM): FSM Department of Health, Education, and Social Affairs, 1999.

120 Snowdon W. Nutritional Survey in Chuuk. Weno, Chuuk: Chuuk State Department of Health, 2000.

121 Rody N. Consumerism in Micronesia. South Pac. Bull. 1978; 28: 9-14.

122 Barker C. Review of the Family Food Production and Nutrition Project. Prepared for the United Nations Children's Fund (UNICEF) Pacific Programme Office, Suva, Fiji, 21 July-30 September 1995. Suva: UNICEF Pacific, 1996.

123 Lloyd-Puryear M, Humphrey JH, West KP, Aniol K, Mahoney J, Keenum DG. Vitamin A deficiency and anemia among Micronesian children. Nutr. Res. 1989; 9: 1007-16.

124 World Health Organization (WHO). Global Prevalence of Vitamin A Deficiency. MDIS Working Paper \#2. Micronutrient Deficiency Information System, WHO/NUT/95.3. Geneva: WHO, 1995.
125 Lloyd-Puryear M, Mahoney J, Humphrey JH, Mahoney F, Siren N, Moorman C, et al. Xerophthalmia, vitamin A deficiency in Micronesia: a state-wide survey in Chuuk. Nutr. Res. 1991; 11: 1101-10.

126 Pryor M, Pryor J, Manning J, Manning S, Rudoy R, Stewart J, et al. Vitamin A deficiency and otitis media in Chuuk State, Micronesia. Pac. Health Dialog 1994; 1(1): 6-12.

127 Mahoney F. Hepatitis B Vaccination Program and Vitamin A Deficiency in Chuuk. Weno, Chuuk: Centers for Disease Control and Prevention and Chuuk State Department of Health Services, 1992.

128 Alnwick D. Combating micronutrient deficiencies: problems and perspectives. Proc. Nutr. Soc. 1998; 75: 1-12.

129 Englberger L. Current vitamin A campaign in Chuuk, Micronesia. Sight and Life Newsletter 1998; 3: 5-7.

130 Englberger L, Elymore J, Meyshine A, Hawley GV. Vitamin A deficiency and vermox (VADAV) campaign in Chuuk State, Micronesia, 1993-1997 [abstract]. In: Proceedings of XIX International Vitamin A Consultative Group Meeting, Durban, South Africa, 8-11 March 1999. Washington, DC: ILSI Research Foundation, 1999; 76.

131 Auerbach S. Report of Pohnpei Child Health Survey. Findings presented to the Federated States of Micronesia (FSM) and Pohnpei State Department of Health Services. Palikir, Pohnpei: US Public Health Service and FSM Department of Health Service, 1994.

132 Englberger L. Promotion of vitamin A-rich foods in Pohnpei, Federated States of Micronesia. Sight and Life Newsletter 1999; 4: 13-7.

133 Sowell A, Gonzaga PS, Englberger L, Schendel D, Elymore J, Huff D. Vitamin A deficiency and anemia among preschool children and their mothers or female caregivers in Yap and Kosrae States, Federated States of Micronesia [abstract]. In: Proceedings of XX International Vitamin $A$ Consultative Group Meeting, Hanoi, Viet Nam, 12-15 February 2001. Washington, DC: ILSI Research Foundation, 2001; 38.

134 Christian P, West KP, Khatry SK, Kimbrough-Pradhan E, LeClerq SC, Katz J, et al. Night blindness during pregnancy and subsequent mortality among women in Nepal: effects of vitamin A and beta-carotene supplementation. Am. J. Epidemiol. 2000; 152(6): 542-7.

135 Draper A, Arthur P, eds. A Study of Factors Influencing Operational Issues for Iron Supplements for Infants and Young Children. Washington, DC: ILSI Press, 2000.

136 World Health Organization (WHO). Physical Status: The Use and Interpretation of Anthropometry. Report of a WHO Expert Committee. WHO Technical Report Series 854. Geneva: WHO, 1995.

137 Shmulewitz D, Auerbach SB, Lehner T, Blundell ML, Winick JD, Youngman LD, et al. Epidemiology and factor analysis of obesity, Type II diabetes, hypertension, and dyslipidemia (syndrome X) on the island of Kosrae, Federated States of Micronesia. Hum. Hered. 2001; 51: 8-19. 